\title{
ANALISIS JAWABAN SISWA TK TERHADAP PEMBELAJARAN KREATIF
}

\author{
Kusmiyati $^{1}$, Rukmini $^{2 凶}$ \\ ${ }^{1}$ IKIP Siliwangi, kusmiyatiassalam@gmail.com \\ ${ }^{2}$ IKIP Siliwangi, dewiirukmini@gmail.com
}

\begin{abstract}
ABSTRAK
Isu-isu pokok penelitian ini adalah bagaimana jawaban-jawaban siswa taman kanakkanak terhadap pembelajaran kreatif. Tujuan dari penelitian ini adalah untuk menganalisis jawaban-jawaban siswa taman kanak-kanak terhadap pertanyaanpertanyaan yang diberikan guru saat pembelajaran di kelas. Metode penelitian yang digunakan adalah metode penelitian deskriptif kuantitatif. Sampel penelitian adalah 36 siswa taman kanak-kanak Al-Hidayah. Hasil penelitian menunjukkan bahwa jawaban-jawaban siswa taman kanak-kanak Al-Hidayah menunjukkan jawabanjawaban secara kreatif pada pembelajaran sains. Guru taman kanak-kanak dapat menggunakan dua jenis pertanyaan terhadap siswa, yaitu pertanyaan tertutup atau terbuka tergantung dengan maksud dan tujuan pertanyaan itu diberikan.
\end{abstract}

Kata Kunci: jawaban siswa, taman kanak-kanak, pembelajaran kreatif.

\begin{abstract}
The main issues of this study are how the answers of kindergarten school students to creative learning. The purpose of this study was to analyze the answers of kindergarten school students to the questions that teachers give when learning in the classroom. The research method used is descriptive quantitative research method. The sample of this research is 36 students of Al-Hidayah kindergarten. The results showed that the answers of kindergarten school students Al-Hidayah show the answers creatively in science learning. Kindergarten school teachers can use two types of questions to students, closed or open questions depending on the intent and purpose of the question given.
\end{abstract}

Keywords: student answers, kindergarten, creative learning.

\section{PENDAHULUAN}

Proses pembelajaran yang diberikan oleh guru di sekolah berkaitan dengan tanya jawab dengan peserta didik berperan penting dalam kegiatan pembelajaran. Sebagian besar guru cenderung menghabiskan $60 \%$ dari waktu pembelajaran mereka dengan memberikan- pertanyaan-pertanyaan (Sullivan \& Lilburn, 2002).

Martino, A. M., \& Maher, (1999)menyatakan bahwa beberapa penelitian menemukan bahwa pertanyaan guru mempengaruhi pertumbuhan pengetahuan konseptual siswa yang membantu kemajuan pemikiran siswa. Pertanyaan juga dapat membantu guru untuk beberapa hal sebagai berikut: untuk mengetahui apakah siswa 
mendengarkan dan memahami pembelajaran, untuk menstimulasi pertumbuhan dan perkembangan siswa, untuk mengembangkan kemampuan berbicara antar siswa dan guru, dan untuk membantu siswa memahami pembelajaran yang diberikan oleh guru(Shahrill, 2013).

Boaler, J., \& Brodie, (2004) menjelaskan bahwa pertanyaan guru memainkan peran yang cukup penting dalam mengendalikan lingkungan kelas dan menciptakan diskusi kelas.Peran-peran ini mengidentifikasi pentingnya pertanyaan guru di kelas. Penelitian sebelumnya dilakukan untuk mengetahui kedekatan antara guru dan siswa, tetapi masih ada beberapa daerah untuk penelitian tentang pertanyaan dan diskusi kelas(Muir, 2009). sebab itu, penelitian mengenai pertanyaan guru yang merangsang diskusi yang kaya masih perlu dianalisis lebih lanjut.

Capraro, M. M., Capraro, R. M., \& Cifarelli, (2007)berpikir bahwa perlu untuk menyediakan siswa dengan banyak pengalaman pemecahan masalah yang mencakup masalah tertutup . Namun, beberapa penelitian menemukan bahwa sebagian besar pertanyaan yang diberikan guru dalam pembelajaran merupakan pertanyaan tertutup yang hanya memiliki satu jawaban yang benar (Muir, 2009; (Kwon, O. N., Park, J. H., \& Park, 2006).

Guru diminta untuk mengajukan berbagai jenis pertanyaan untuk merangsang kreativitas sebagai salah satu standar dari kurikulum (Kwon, O. N., Park, J. H., \& Park, 2006). Kwon, O. N., Park, J. H., \& Park, (2006) percaya bahwa pendidikan sains harus menekankan kreativitas untuk miningkatkan kemampuan siswa dalam mengembangkan berbagai solusi ketika menjawab pertanyaan. Meskipun kreativitas diperlukan dalam pembelajaran sains, masih dipertanyakan jenis kreativitas siswa di kelas. Oleh karena itu, masih menjadi masalah yang bisa dipelajari.

Guru harus mempertimbangkan bagaimana mereka harus memberikan pertanyaan bagi siswa, mendorong siswa untuk memberikan jawaban mereka (Cotton, 2001). Guru juga dapat menanyakan pertanyaan lisan atau tertulis kepada individu atau kelompok siswa.(Cotton, (2001)menyarankan agar guru melakukan teknik waktu menunggu setelah mengajukan pertanyaan dimana guru memberikan waktu bagi siswa untuk mempertimbangkan tentang pertanyaan sebelum menjawab karena kadang-kadang siswa tidak dapat menjawab pertanyaan secara langsung.

Boaler, J., \& Brodie, (2004)mengklasifikasikan pertanyaan guru ke dalam sembilan kategori berdasarkan tujuan dan teknik pertanyaan guru, mereka akan sulit digunakan untuk analisis karena beberapa kategori memiliki arti yang serupa. Yee, (2002)membagi jenis pertanyaan mengenai jumlah kemungkinan jawaban yang benar, menjadi dua jenis pertanyaan, pertanyaan tertutup dan terbuka.Pertanyaan tertutup hanya memiliki satu jawaban yang benar sementara pertanyaan terbuka memiliki banyak jawaban.

Muir, (2009)mengklasifikasikan respon jawaban siswa ke dalam penjelasan, berbagi, pembenaran, tantangan dan jawaban.Penjelasan berbeda untuk berbagi karena siswa diminta untuk mengungkapkan kata-kata atau strategi mereka.Pembenaran mengacu pada ketika siswa menguraikan penjelasan mereka, biasanya terjadi ketika menanggapi pertanyaan yang membutuhkan pembuktian.Tantangan diberikan oleh siswa sementara mereka mempertanyakan atau menantang jawabannya. Jika peserta didik mengutarakan jawaban atau menanggapi dengan singkat, tanggapan ini akan disebut sebagai jawaban.

Tiga bagian kreativitas yang diteliti adalah kelancaran (jumlah jawaban yang berbeda), fleksibilitas (jumlah strategi untuk memecahkan pertanyaan), dan orisinalitas (betapa jarang jawaban dalam mengatur semua pertanyaan atau kekerapan jawaban).Kwon et al. (2006)menemukan bahwa pertanyaan terbuka efektif dalam mendorong kreativitas siswa karena pertanyaan-pertanyaan ini memungkinkan siswa untuk menerapkan strategi dalam menemukan beragam jawaban yang mungkin baru.

\section{a. Rumusan Masalah}

Merujuk dari permasalahan yang telah disampaikan, peneliti bermaksudmencari jawaban untuk dua pertanyaan penelitian sebagai berikut: 
1. Bagaimana pendidik memberikan stimulus kepada siswa?.

2. Kreativitas yang bagaimana yang diungkapkan siswa melalui jawaban siswa terhadap pertanyaan di kelas?

\section{b. Batasan Penelitian}

Batasan-batasan penelitian sebagai berikut:

1. Penelitian ini dibatasi pada siswa taman kanak-kanak.

2. Indikator yang diukur adalah jawabanjawaban yang diungkapkan oleh peserta didik saat pembelajaran sains berlangsung.

\section{c. Tujuan Penelitian}

Penelitian ini berujuan untukmengetahui jawaban-jawaban yang diungkapkan peserta didik terhadap stimulus yang diberikan pendidik saat pembelajaran sains dilakukan.

\section{d. Target Luaran} berikut:

Target-target luaran penelitian sebagai

1. Adanya instrumen yang valid dan reliabel untuk mengukur jawaban-jawaban yang diungkapkan peserta didik TK pada materi sains.

2. Data-data dan fakta saat kegiatan ini dilakukan bisa menjadi bahan kajian lanjutan penulisan artikel berikutnya dan bisa dipublikasikan pada jurnal nasional dan internasional.

3. Sebagai materi untuk penelitian berikutnya.

4. Tersosialisasinya materipenelitian kerjasama pembimbing dan mahasiswa serta taman kanak-kanak tempat penelitian.

\section{METODE PENELITIAN}

Metode penelitian yang digunakan adalah metode penelitiandeskrptif kuantitatif.Penelitian ini melibatkan seorang guru perempuan yang mengajar sains untuk siswa-siswa taman kanakkanak sebanyak 36 siswa.

Data yang dikumpulkan menggunakan pedoman observasi dan wawancara. Pengamatan dilakukan untuk mengetahuicara guru memberikan pertanyaan, jenis pertanyaan, dan jawaban yang diberikan oleh siswa.
Selama pengamatan, kegiatan pembelajaran di kelas dicatat, catatan juga diambil, dan contoh karya siswa dikumpulkan secara acak.Rekaman video pembelajaran ditranskripsi, kemudian peneliti melakukan wawancara berdasarkan tujuan penelitian dan masalah yang ditemukan saat pengamatan di kelas yang memerlukan klarifikasi.

Proses wawancara melibatkan guru dan lima siswa untuk mengklarifikasi pengamatan yang telah dilakukan dan menganalisis seperti apa kreativitas sains siswa tersebut. Wawancara ini juga direkam dan ditranskrip.

Peneliti memastikan bahwa data yang diperoleh tersebut valid dengan menerapkan ketepatan alat, proses, dan data (Leung, 2015). Peneliti juga tidak terlibat dalam proses pembelajaran dimana peneliti dapat mencegah interpretasi bias selama proses pengumpulan data.

Para peneliti sebelumnya Chin, 2007; (Franke, et al, 2009; Martin, A. M., \& Hand, 1999; Muir, 2009)menggunakan metode serupa untuk menyelidiki kegiatan bertanya guru meskipun mereka memiliki tujuan penelitian yang berbeda. Leung(2015)menyatakan bahwa peneliti harus memastikan konsistensi dari proses dan temuan penelitian mereka. Selama pengumpulan data, peneliti menerapkan pendekatan yang sama menggunakan rekaman suara dan kemudian menyalinnya dengan memutar perekam beberapa kali.

\section{a. Lokasi Penelitian}

Lokasi penelitian yang digunakan adalah taman kanak-kanak Al-Hidayah Kota Cimahi.

\section{b. Peubah yang Diamati/Diukur}

Peubah yang diamati atau diukur dalam penelitian ini adalah jawaban siswa yang diberikan selama pembelajaran sains dilakukan di kelas.

\section{c. Model yang Digunakan}

Model yang digunakan dalam penelitian ini adalah model pembelajaran sains menggunakan teknik tanya jawab.

\section{d. Analisis Data}


Data yang dikumpulkan dianalisis secara statistik menggunakan SPSS, diinterpretasikan menggunakan persentase, dan dideskripsikan.

\section{HASIL DAN PEMBAHASAN}

Selama pembelajaran, guru mengajarkan tentang sains.Guru menyatakan bahwa dia menerapkan dua metode bertanya, meminta siswa secara lisan dan memberi tugas tertulis kepada siswa. Jika guru mengajar secara lisan mungkin pertanyaannya datang secara lisan. Guru pikir siswa tidak perlu memiliki lembar kerja setiap pelajaran sehingga lembar kerja hanya diberikan dari guru. Terkadang, pertanyaan itu tergantung pada subjek. Jika ingin jawaban ya atau tidak dari siswa, guru harus menggunakanpertanyaan tertutup.

Jika guru menginginkan pemahaman yang lebih dalam, guru menggunakan pertanyaan openended karena pertanyaan tersebut dapat membuat siswa berpikir dan menghasilkan ide-ide yang berbeda, dan dapat memperluas pembelajaran.Jadi, guru berpikir bahwa guru dapat melakukan keduanya.Pertanyaan lebih terbuka dapat diberikan terutama dalam sains karena guru ingin melihat hubungan antara konsep daripada hanya berpikir.

Ketika ditanya apa yang guru pikirkan tentang kebenaran jawaban siswa, guru mengatakan dia yakin tidak ada jawaban yang salah. Guru percaya hanya ada kesalahpahaman. Jadi, guruakan bekerja dengan jawaban siswa dan mencoba memberikan pertanyaan lanjutan kepada mereka untuk membuat mereka menyadari tentang kesalahan jawaban mereka dan mendapatkan jawaban yang benar.

Pertanyaan yang bagus memungkinkan untuk kesalahan dan gurudapat membangun lebih banyak pertanyaan dari yang telah diberikan sebelumnya.

Guru dapatmenanyakan berbagai jenis pertanyaan dengan menggunakan teknik yang berbeda, mengajukan banyak pertanyaan secara lisan. Guru juga menggunakan slide pada PowerPoint untuk mengilustrasikan pertanyaan, meminta siswa untuk menuliskan jawaban dalam buku latihan mereka. Oleh karena itu, guru mengajukan pertanyaan baik lisan maupun tulisan.

Gurudapat melakukan teknik menunggu waktu, menunggu jawaban siswa. Guru juga dapat secara spontan mengembangkan pertanyaan tambahan berdasarkan jawaban siswa untuk mengeksplorasi ide-ide siswa lebih lanjut dan melibatkan seluruh kelas untuk memeriksa jawabannya. Melalui proses ini, para siswa dapat berbagi ide mereka satu sama lain dan menyelidiki apakah jawabannya benar atau tidak.

Dalam topik lain, sudut pandang guru tidak hanya mengajukan pertanyaan kepada seorang individu tetapi juga menginstruksikan siswa untuk mendiskusikan secara berpasangan untuk menjawab pertanyaan-pertanyaan yang diberikan.

Terdapat 30 jenis pertanyaan yang diberikan guru selama pembelajaran, 10 pertanyaan tentang sains dan sisanya tentang hubungan sains dan lingkungan.20 pertanyaan ditutup, dan 10 pertanyaan merupakan pertanyaan terbuka. Guru menanyakan beberapa ekspresi yang berbeda dalam menanyakan pertanyaan tertutup atau terbuka.

Dengan demikian, terlihat bahwa guru menanyakan pertanyaan tertutup dan terbuka selama pembelajaran. Dalam wawancara, guru menyatakan bahwa dia menanyakan pertanyaan berdasarkan subjek dan apa yang diinginkannya agar siswa memperolehnya. Dia akan mengajukan pertanyaan tertutup ketika menanyakan yang hanya memerlukan jawaban ya atau tidak.

Guruakan mengajukan pertanyaan terbuka jika guru ingin mendorong siswa untuk berpikir secara mendalam dan menghubungkan konsep sains dengan banyak ide. Ketika mengajukan pertanyaan tertutup, guru mencoba mendorong siswa untuk menganalisis apa yang dimaksud dengan pertanyaan, misalnya, ketika guru bertanya tentang hubungan sains dan lingkungan yang mendorong siswa untuk berpikir tentang makna hubungan sains dan lingkungan.

Lebih jauh lagi, guru mengajukan siswa masalah yang merupakan salah satu jenis pertanyaan terbuka, sebuah masalah terbuka (Yee, 2002), dimana guru meminta siswa untuk membuat pertanyaan mereka sendiri berdasarkan 
pernyataan yang guru berikan. Dari masalah terbuka ini, guru berhasil mengangkat jawaban yang berbeda dari siswa.Guru juga mendorong siswa untuk menganalisis kesalahan jawaban teman-teman sekelas mereka dengan bertanya apakah itu benar.

Siswa dapat belajar untuk menyelidiki kebenaran jawaban.Selain itu, guru mengembangkan keterampilan komunikasi dan penalaran siswa dengan bertanya ari mana asalnya, bagaimana, dan mengapa.

Terdapat beberapa jawaban secara lisan yang diberikan siswa selama pembelajaran.Jawabanjawaban ini lebih dari jumlah pertanyaan yang diminta oleh guru karena beberapa pertanyaan terbuka menghasilkan banyak jawaban dari siswa. Dari menganalisis transkrip dari keseluruhan observasi, para siswa memberikan jawaban yang dikategorikan ke dalam 15 penjelasan, 3 pembenaran dan 50 jawaban singkat.

Sebagian besar siswa menjelaskan alasan dibalik jawaban mereka ketika menghadapi pertanyaan mengapa dan bagaimana serta memberikan jawaban singkat ketika guru memberikan pertanyaan ya atau tidak yang merupakan pertanyaan tertutup. Instruksi guru untuk membuat pernyataan berdasarkan pertanyaan dapat mendorong pembenaran jawaban siswa.

Kreativitas sains siswa yang berkaitan dengan kelancaran, fleksibilitas, dan orisinalitas dapat dilihat dari jawaban-jawaban siswa untuk pertanyaan terbuka.Terdapat sepuluh jawaban berbeda (kefasihan) yang diberikan siswa dimana guru memuji tiga jawaban (orisinalitas).Sebagian besar siswa menjawab dengan satu operasi dasar.Satu siswa mengajukan pertanyaan menggunakan dua operasi dasar (fleksibilitas).

Jawaban-jawaban siswa untuk tugas menunjukkan beberapa kelancaran.Untuk ide sains (fleksibilitas), sebagian besar siswa diasumsikan mereka berbeda dengan mempertimbangkan jawaban-jawaban sainsnya.Tiga siswa lainnya berpikir bahwa sains ilmu yang jelas.Namun, mereka menemui kebingungansehingga mereka menganggap jawaban-jawaban mereka mirip.
Keaslian jawabansiswa tersebut tidak dapat ditentukan karena peneliti tidak memiliki jawaban perbandingan yang cukup untuk semua siswa di kelas. Meskipun siswa diminta langsung untuk memberikan jawaban dari sudut pandang yang berbeda dalam wawancara, kebanyakan siswa tetap memberikan jawabanyang hampir sama.

Guru dalam penelitian ini menghabiskan sebagian besar pembelajaran dengan mengajukan pertanyaan secara lisan. Apakah itu lebih baik bagi siswa masih tidak dapat dilihat secara langsung karena guru memiliki tujuan dan alasan mengapa dia melakukannya. Guruterlihat berusaha melakukan pertanyaan efektif untuk pembelajaran dengan mengajukan pertanyaan tertutup dan terbuka.

Pertanyaan tertutup membuat siswa menjawab dengan benar atau salah karena pertanyaan-pertanyaan itu memiliki jawaban yang tepat.Namun, guru tidak menggunakan pertanyaan terbuka hanya untuk memeriksa kebenaran jawaban, tetapi lebih fokus pada pengembangan komunikasi siswa, ide-ide sains, penalaran, dan keterampilan pemecahan masalah (Kwon et al., 2006).Oleh karena itu, jawaban yang benar dan salah adalah penting bagi guru.

Hasil penelitian ini menemukan bahwa guru tidak mencari kebenaran jawaban siswa selama pembelajaran. Namun, pemikiran guru ini harus diselidiki lebih lanjut di masa depan karena guru mungkin peduli dengan kebenaran jawaban dalam pembelajaran yang berbeda berdasarkan pada tujuan pembelajarannya.

Pertanyaan terbuka tampaknya memupuk kreativitas sains siswa(Kwonet al 2006), tetapi untuk mengevaluasi kreativitas sains siswa, guru menghadapi kesulitan terutama mencari keaslian ide-ide siswa. Kategori ide orisinil mungkin berbeda untuk guru yang berbeda karena pengalaman pribadi dan penilaian mereka terhadap ide tersebut.

Pertanyaan terbuka yang mendorong siswa untuk menghasilkan banyak jawaban juga menantang para guru untuk berpikir cepat apa yang harus mereka lakukan untuk menanggapi jawaban yang tidak terduga. Kadang-kadang, guru juga perlu memberikan pertanyaan tambahan untuk mendorong siswa untuk berpikir 
lebih jauh tentang jawaban mereka, terutama ketika mereka memiliki kesalahpahaman tentang pertanyaan.

\section{KESIMPULAN}

Guru memiliki pertimbangan sendiri dalam mengajukan pertanyaan, sehingga apa yang telah dilakukan guru dalam penelitian ini mungkin berbeda dengan guru lain. Guru menentukan jenis pertanyaan yang ingin mereka tanyakan berdasarkan tujuan pembelajaran mereka. Pertanyaan terbuka dapat digunakan oleh guru tidak hanya untuk menghasilkan kreativitas sains, tetapi juga mengembangkan pertanyaan tambahan untuk merangsang pemikiran siswa dan menganalisis kesalahpahaman siswa lebih lanjut.

\section{UCAPAN TERIMAKASIH}

Dengan segala hormat dan kerendahan hati, tim penulis memanjatkan puji syukur kehadirat Allah SWT atas segala rahmat dan karunia-Nya, sehingga tim penulis dapat menyelesaikan artikel ilmiah ini.

Dalam pembuatan artikel ilmiah ini, tim penulis mendapatkan arahan, bantuan, dan bimbingan yang sangat berharga dari berbagai pihak. Pada kesempatan ini, tim penulis mengucapkan terima kasih yang sebesar-besarnya kepada pembimbing, teman-teman satu tim penelitian, sekolah dasar tempat penelitian ini dilakukan, serta tim pengelola dan tim reviewer artikel jurnal yang telah meluangkan waktu dan kesempatannya untuk memberikan kesempatan dan arahan sehingga artikel ini dapat dipublikasikan.

\section{DAFTAR PUSTAKA}

Boaler, J., \& Brodie, K. (2004). The importance, nature, and impact of teacher questions. In Proceedings of the twenty-sixth annual meeting of the North American Chapter of the International Group for the Psychology of Mathematics Education. PMENA, 2, 774790.

Capraro, M. M., Capraro, R. M., \& Cifarelli, V. V. (2007). What are students thinking as they solve open-ended mathematics problems?. In Proceedings of the ninth international conference of Mathematics Education in a Global Community. North Carolina.

Chin, C. (2007). Teacher questioning in science classrooms: Approaches that stimulate productive thinking. Journal of Research in Science Teaching. 815843, 44(6).

Cotton, K. (2001). Classroom questioning. School improvement research series, 3 .

Franke, M. L., Webb, N. M., Chan, A. G., Ing, M., Freund, D., \& Battey, D. (2009).

Teacher questioning to elicit students' mathematical thinking in elementary school classrooms. Journal of Teacher Education. Journal of Teacher Education, 60(4), 380392.

Kwon, O. N., Park, J. H., \& Park, J. S. (2006). Cultivating divergent thinking in mathematics through an open-ended approach. Asia Pacific Education Review, 7(1), 51-56.

Leung, L. (2015). Validity, reliability, and generalizability in qualitative research. Journal of Family Medicine and Primary Care,

Martin, A. M., \& Hand, B. (1999). Factors affecting the implementation of argument in the elementary science classroom. A longitudinal case study. Research in Science Education, 18(1), 53-78.

Martino, A. M., \& Maher, C. A. (1999). Teacher questioning to promote justification and generalization in mathematics: What research practice has taught us. The Journal of Mathematical Behavior, 18(1), 53-78.

Muir, T. (2009). Investigating teachers' use of questions in the mathematics classroom. In International Group for the Psychology of Mathematics Education, 4, 161-168.

Shahrill, M. (2013). Review of teacher questioning in mathematics classrooms. International Journal of Humanities and Social Science, 3(17), 224-231.

Yee, F. P. (2002). Using short open-ended mathematics questions to promote thinking and understanding. 


\section{JURNAL CERIA}

ISSN : 2614-6347 (Print) 2614-4107 (Online)

Vol1_ لـ لـ 2018 